\title{
Determining factors in the social entrepreneurial profile of young university student
}

\section{Factores determinantes del perfil emprendedor social de jóvenes universitarios}

\author{
CALDERA-GONZÁLEZ, Diana del Consuelo ‘**, ACOSTA-CASTILlO, María Guadalupe de \\ Lourdes" and RUIZ-SAN ROMÁN, José Antonio
}

\author{
'Universidad de Guanajuato, Fraccionamiento 1; Col. El Establo S/N; C.P. 36250; Guanajuato, Gto., México. \\ "Instituto Tecnológico Superior de Guanajuato, Carretera Guanajuato a Puentecillas Km 10.5; Puentecillas; 36262; \\ Guanajuato, Gto., México. \\ "Universidad Complutense de Madrid, Avenida Complutense, s/n 28040, Madrid, España. \\ ID $1^{\text {st }}$ Author: Diana del Consuelo, Caldera-González / ORC ID: 0000-0003-2116-2538, CVU CONACYT ID: 46851 \\ ID $1^{\text {st }}$ Coauthor: María Guadalupe de Lourdes, Acosta-Castillo / ORC ID: 0000-0003-4456-8362, CVU CONACYT ID: \\ 527101 \\ ID $2^{\text {nd }}$ Coauthor: José Antonio, Ruiz-San Román / ORC ID: 0000-0003-3161-0330
}

\begin{abstract}
Social entrepreneurship focuses on solving problems of a collective nature through new ideas that allow the improvement of the environment. This research aims to advance in the understanding of the crucial factors that profile the social entrepreneur, which represents new opportunities to identify, strengthen and design strategies from the University aimed at the creation of enterprises with social value. This research is quantitative, non-experimental and descriptive. A survey was applied to an incidental sample of 515 university students and the data was processed based on a Principal Components Analysis (ACP), which presents the factors that have the greatest influence on the two selected components. The coefficients found indicate that the first component is related to the factors: creativity and innovation; self-confidence or internal control; adaptability and tolerance to failure; while the second component receives a greater contribution in the factors: perseverance and commitment; adaptability and tolerance to failure; and finally self-confidence and internal control.

* Research funded by the Dirección de Apoyo a la Investigación y el Posgrado, University of Guanajuato
\end{abstract}

Social entrepreneurship, Crucial factors, University students

\begin{abstract}
Resumen
El emprendedurismo social se enfoca en resolver problemas de índole colectivo mediante nuevas ideas que permitan el mejoramiento del entorno. Esta investigación se propone avanzar en la comprensión de los factores determinantes que perfilan al emprendedor social, lo cual representa nuevas oportunidades para identificar, potenciar y diseñar estrategias desde la Universidad encaminadas a la creación de emprendimientos con valor social. Esta investigación es de tipo cuantitativo, corte no experimental y con alcance descriptivo. Se aplicó una encuesta a una muestra incidental de 515 estudiantes universitarios y el tratamiento de los datos se realizó a partir de un Análisis de Componentes Principales (ACP), el cual presenta los factores que tienen una mayor influencia en los dos componentes seleccionados. Los coeficientes encontrados indican que el primer componente se relaciona con los factores: creatividad e innovación; autoconfianza o control interno; adaptabilidad y tolerancia al fracaso; mientras que el segundo componente recibe una mayor aportación en los factores: perseverancia y compromiso; adaptabilidad y tolerancia al fracaso; y finalmente autoconfianza y control interno.

*Investigación financiada por la Dirección de Investigación y Apoyo al Posgrado de la Universidad de Guanajuato
\end{abstract}

Emprendedurismo social, Factores determinantes, Jóvenes universitarios

Citation: CALDERA-GONZÁLEZ, Diana del Consuelo, ACOSTA-CASTILLO, María Guadalupe de Lourdes and RUIZSAN ROMÁN, José Antonio. Determining factors in the social entrepreneurial profile of young university students. Journal Schools of economic Thought and Methology. 2019. 3-5: 1-8.

\footnotetext{
* Correspondence to Author (email: dccaldera@ugto.mx)

$\dagger$ Researcher contributing as first author.
} 


\section{Introduction}

The present work is focused on entrepreneurship with a social approach applied to young people, since they are susceptible to the acquisition of new knowledge, to the generation of new ideas and to face new challenges, so it is important to change the traditional teaching method and focus on students acquiring new skills and abilities according to current needs.

There are programs in the Universities for the creation of companies, which involves the topic of entrepreneurship, however, the current educational models still fail to develop the skills and abilities in students to develop social entrepreneurship.

Social entrepreneurship is a necessary issue for economic development and growth, as well as to improve people's standard of living (social development). Entrepreneurship means generating ideas and being in constant innovation. Social entrepreneurship not only seeks to generate resources, but also seeks to bring a benefit to the community, achieving the well-being of people in a sustainable way.

Therefore, it becomes a pressing task to identify those factors that promote or inhibit social entrepreneurship in young university students.

\section{Objective}

The objective of this work is to advance in the understanding of the determining factors that profile the social entrepreneur from a Principal Components Analysis (ACP) and the application of a survey. The research question was: What factors are decisive in the profile of the young university social entrepreneur?

\section{Theoretical basis}

As it has been commented, in general terms, social entrepreneurship is oriented in solving problems of collective nature by creating companies and new ideas that allow the improvement of the environment.
Martínez and Rodríguez (2013) affirm: Social entrepreneurship focuses on innovation and social change; look for a base capital to reinvest and grow. These types of companies confuse many who mistakenly believe that social entrepreneurship corresponds to non-profit companies that do not require generating economic resources, when in reality they are companies that need funds to meet their social objective, the fact of obtaining a profit is only a means to achieve a goal (p.105).

As it is possible to appreciate, social entrepreneurship must be economically sustainable through the creation of profits, which will serve as a vehicle to meet the goal of satisfying social problems, contributing to the welfare of the population.

From another perspective, Caldera, Ortega and Sánchez (2016) consider that "Social entrepreneurship has several characteristics such as sustainability, the promotion of people's participation, attention to social problems with diverse objectives, the search for a benefit economic and a social transformation" (p. 2244).

For Becerra, Cortés, Malacara and Alegria (2014), social entrepreneurship must develop and achieve satisfactory results, for this, it is unavoidable to integrate several factors in a relevant way, such as planning strategies to access government support and programs, develop a project with a Functional administrative structure, design a collaboration scheme focused on communities and their peculiarities, centralize the coordination and direction of the project in an ideal leader to foster a deep conviction of the protagonists, with high social vocation, capable of identifying synergies, strategic alliances and the necessary linkages for the development of social projects.

Additionally, Marulanda and Morales (2016) mention that in a venture the following factors must converge: the aspirations or motivations of the creator; competencies, skills and know-how; financial and logistic resources; the network of relationships; and the environment for creation, which refers to the opportunities offered by the market and the incentives provided by the legal framework for entrepreneurial activity. 
In the same vein, Rodríguez and Prieto (2009) point out that the cultural context is decisive for entrepreneurship and evokes the importance of the existence of favorable environments in the countries for the culmination of business ideas and even highlights the importance of the support of the governments in the creation of companies, the efficiency of bureaucracy in the legalization of business projects and the accompaniment of chairs in universities on entrepreneurship.

Thus, it is possible to appreciate that, the achievement of social entrepreneurship is based on a mixture of factors, some external to the individual and others internal, but always considering both dimensions and obviously placing the analysis in a specific geographical and temporal space.

For example, Torné and Suárez (2019) analyzed the impact of studying at the University the subject of Business Creation in the entrepreneurial intention of economics students, finding that, at the end of the course, the number of students who expressed their idea of create a company, improving their knowledge regarding the creation and management of companies, but decreased their intention and entrepreneurial attitude; that is to say, that it is not exclusively about stimulating the entrepreneurial spirit from the University, but that it is necessary to identify the internal factors that predispose the student to entrepreneurship and the external factors that will lead him to a good course or, to the abandonment of the same.

Regarding these factors, Mancilla and Amorós (2012) address aspects such as psychological, sociocultural, socio-demographic and social context; to which, according to Capella, Gil, Martí and Ruiz, (2016), we must add the behaviors, values, attitudes and traits that exist in the entrepreneurial personality and entrepreneurial behavior, which affect the impact on the individual decisions of people to become entrepreneurs.

Other authors such as Messina and Hochsztain (2015) and Leiva (2013), point out that sociodemographic factors are important and foreign to the entrepreneur; These factors are: sex, age and context (culture, values, formal and informal norms, institutions and others).
In this same way, Sepúlveda and Gutiérrez (2016) mention that within the skills and traits of an entrepreneur are age, training level, experience among others; and in the environmental factors are the characteristics of the region where the company is located, the people and traditions that surround the organization, as well as the influences that appear on the development of the company such as economic growth, the nature of the sector, geographic location, among others. At the beginning of a new project, most entrepreneurs have a vision or dream that they want to achieve, however, for many reasons this initial idea is not achieved, which represents frustration and failure for some entrepreneurs, which is why they must also understand people's behaviors. One of the factors that drives entrepreneurs to overcome difficulties such as lack of resources, competition or hostile environment, is the motivation since it exhibits biological and cultural aspects of people, therefore, many of the adaptive challenges to that human beings face have individual and social evocations (Palmero, 2005).

Thus, it is possible to affirm that both external and internal factors influence the development of the social entrepreneur. In this regard, Mora, Aguirre, Álava and Cordero (2019), based on their research, affirm that the university entrepreneurial ecosystem, as well as the approval of family, friends and professors positively influence the social entrepreneurial intention of young university students. In a complementary way, Pat and Basto (2019), propose that the main limitation to undertake in university students is the lack of knowledge related to the topic of entrepreneurship and its financing, since the motivation to undertake comes from its economic situation and The desire for personal growth. Coinciding in the relevance of the consent of family, partners and friends. Following Caldera, Ortega and Sánchez (2016), there is a great diversity of definitions and approaches about the term social entrepreneur, which derives from the complexity and multidimensionality of its essence; well, different perspectives on the factors that determine the social entrepreneurial profile can be considered, however, as we have seen, they all converge on the separation of internal and external dimensions for analysis. 
In the following section, the factors chosen for the analysis in this research work will be mentioned and described.

\section{Analysis Dimensions}

For this work, we began by selecting and analyzing seven factors, which are defined below:

1. Creativity / innovation: The capacity for innovation is related to perceiving and acting in business with new and unique activities. It is the fundamental aspect of entrepreneurship and an essential characteristic of an entrepreneur.

2. Self-efficacy / internal control (control locus): It is an attribute of individual competence that implies control in a given situation. Measure the belief and security of the person, with their own abilities, to perform a specific task.

It is related to the belief that the actions that one performs determine the results that are obtained, that is, a greater perception of control and self-efficacy of a person's behavior is the intention of a person to become an entrepreneur.

3. Adaptability / tolerance to failure: It is the personality trait that determines the tendency and ability of an individual to take risks, that is to say that entrepreneurs operate in an environment of uncertainty, with an aim towards the unknown.

4. Perseverance / commitment: It is the willpower that leads us to conclude something we set out to do, even if internal or external difficulties arise, or even if personal motivation decreases.

5. Knowledge of the environment: The ability to create and build something from the information available in the environment, mainly in the social, economic, political fields; and at a different level such as local, regional, national and even international.
6. Social empathy: The entrepreneur is empathetic when living and feeling in their own flesh the social experiences of others. In the case of social entrepreneurship, empathy is a key element to achieve a successful venture.

Entrepreneurial University: This is about the stimulation of higher education institutions to grow the entrepreneurial potential of their students. It gives them the right space and knowledge to detonate their ideas and create value in society. They promote project initiatives to create new products that meet needs in society or develop new processes. For universities, this initiative arises from the need to induce economic and social development and growth.

\section{Methodology}

This research is quantitative, non-experimental and descriptive. For the development of the research, an incidental sample of 515 students from 22 Mexican higher education institutions from 30 different degrees was selected, to which the Social Entrepreneur Profile (PES v1) instrument was applied, an instrument built with 25 items on the Likert scale associated with the seven social entrepreneurship factors mentioned in the previous section (Caldera, 2019).

As an initial part, a Principal Components Analysis (ACP) was carried out where a representation of the seven elements of social entrepreneurship represented by 24 variables included in the information collection instrument was carried out.

The ACP retains components with eigenvalues greater than 1.0, obtaining new orthogonal dimensions, maximizing the sum of the variances of the vectors so that in this way all the coefficients are greater than or near zero.

The purpose is to associate each variable with at least one of the components (Solanas et al., 2011). Figure 1 presents the percentage of variance for the first 10 main components defined with the analyzed data, where one of the factors absorbs much of the information obtained. 


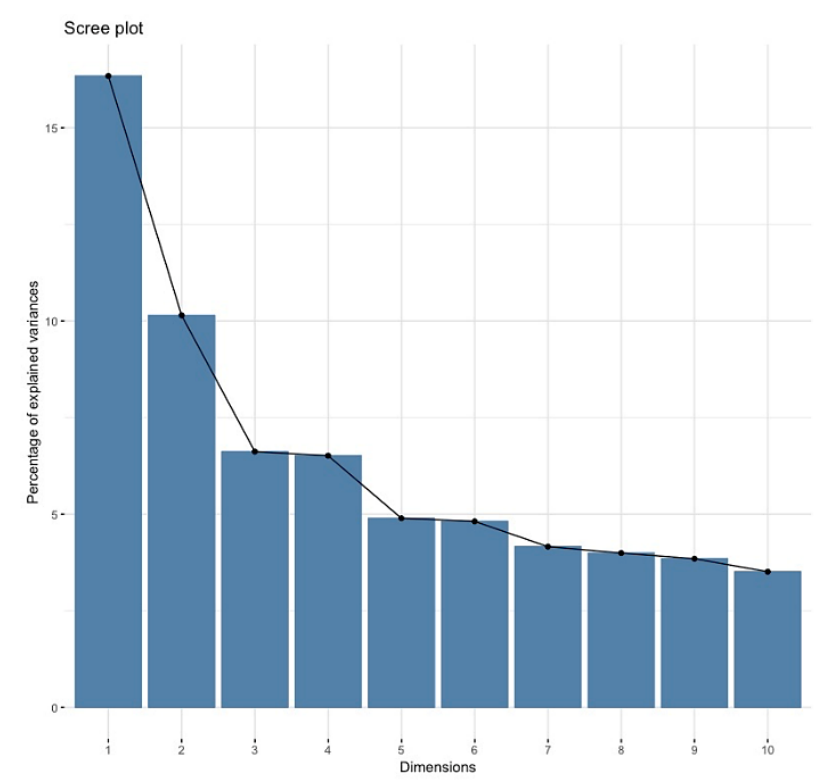

Figure 1 Percentage of variance for the first 10 main components

Source: self-made

In the $\mathrm{ACP}$, it seeks to capture the least number of variables including the greatest amount of variance. In this case, the first two components capture more than $25 \%$ in the sum of their variances, so they were selected to be represented in a two-dimensional space.

ACP is used in a wide variety of psychology and sociology research fields, but it can be applicable to many other research fields. For the development of the ACP, the size of the data obtained is reduced, where the high coefficients between the variables and the main components indicate a high level of correlation (Ramírez, Antúnez and Rodríguez, 2016).

Table 1 presents the correlation coefficients for the two main components of the internal and external factors of social entrepreneurship, where the values with the highest positive and negative correlation between the variables and the components have been indicated. These coefficients contribute significantly to the transformation of the variables for the interpretation of the ACP.

\begin{tabular}{|l|r|r|}
\hline Variable & \multicolumn{2}{l}{ PC1 } \\
\hline CI_1 & -0.2125137 & 0.12516774 \\
\hline CI_2 & $\mathbf{- 0 . 2 9 1 8 7 3}$ & $\mathbf{- 0 . 0 4 5 4 2 2 4}$ \\
\hline AT_1 & $\mathbf{- 0 . 2 7 5 9 0 8 1}$ & 0.01308665 \\
\hline AT_2 & 0.15852723 & $\underline{0.353125}$ \\
\hline AC_1 & -0.1822337 & 0.0084479 \\
\hline ES_1 & -0.1952179 & 0.13760609 \\
\hline CE_1 & -0.2542001 & 0.11539548 \\
\hline ES_2 & -0.2672181 & 0.08099288 \\
\hline AC_2 & $\mathbf{- 0 . 2 7 4 3 0 6}$ & 0.08528343 \\
\hline UE_1 & -0.1326807 & 0.24594019 \\
\hline
\end{tabular}

December, 2019 Vol.3 No.5 1-8

\begin{tabular}{|l|r|r|}
\hline AC_3 & 0.08393509 & 0.29373794 \\
\hline AC_4 & $\underline{0.20663219}$ & $\underline{0.37472269}$ \\
\hline CE_2 & -0.1255669 & 0.08520756 \\
\hline CE_3 & -0.045254 & 0.24057866 \\
\hline PC_1 & 0.10206176 & 0.27983254 \\
\hline PC_2 & 0.13594757 & 0.36228059 \\
\hline PC_3 & -0.266179 & 0.04585529 \\
\hline CI_3 & $\mathbf{- 0 . 2 7 3 0 4 9 1}$ & -0.0139028 \\
\hline ES_3 & -0.2627943 & 0.09056065 \\
\hline ES_4 & -0.2360068 & 0.13972231 \\
\hline ES_5 & 0.14989738 & 0.17484058 \\
\hline AC_5 & 0.11652635 & 0.32413218 \\
\hline UE_2 & -0.1046172 & 0.24814141 \\
\hline UE_3 & -0.2336384 & 0.14880573 \\
\hline
\end{tabular}

Table 1 Correlation coefficients for the main components Source: own source

As can be seen, the variables CI_2 (creativity / innovation 1), AT_1 (adaptability / tolerance to failure 1), AC_2 (self-confidence / internal control 2), CI_3 (creativity / innovation 3), corresponding to the highest negative correlation between them and the PC1 component; while AC_4 (self-confidence / control 4) marked with gray represents the highest positive correlation with the same component. For component PC2, the variable CI_2 (creativity / innovation 2) appears in bold with the highest negative correlation and the variables AT_2 (adaptability / tolerance to failure 2), AC_4 (self-confidence / internal control 4) and PC_2 (perseverance / commitment 2 ) in gray with the highest positive correlation.

\section{Results}

The ACP allows identifying the variables that have a greater or lesser influence on the two components selected according to their positive or negative correlation. The coefficients found indicate that the first component is related to creativity / innovation, self-confidence / internal control, and adaptability / tolerance to failure; while the second component receives a greater contribution in perseverance / commitment, adaptability / tolerance to failure and selfconfidence / internal control.

The influence shown by these variables could relate the PC 1 component to external factors and internal factors, placing students on the positive axis of the component as those with the greatest influence of external factors and on the negative axis to students with greater influence of internal factors. 
The PC_2 component could be related to the level of social entrepreneurship, where students located in the positive or negative axis show a greater or lesser influence of it.

Figure 2 shows on the horizontal axis the first component and the vertical axis represents the second main component with the observations of the elements of the sample.

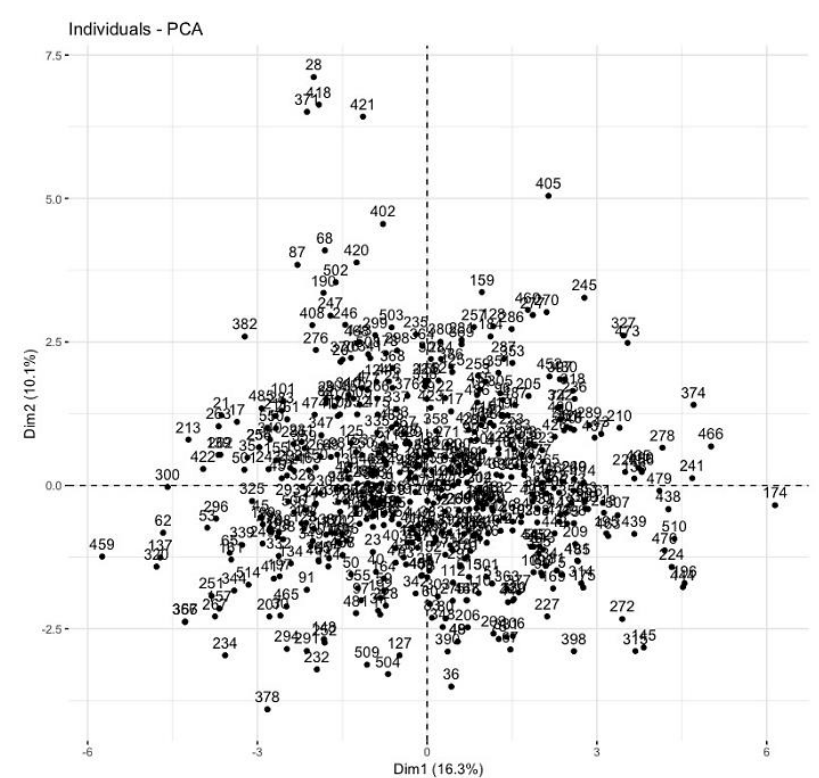

Figure 2 Graphical representation of the elements of the sample in two main components

Source: own source

The first quadrant located in the upper right places students who have a positive influence on social entrepreneurship and external factors; while, in the second lower right quadrant, students who receive positive influence from social entrepreneurship and internal factors are located.

The third lower left quadrant places students who receive influence of internal factors and negative influence of social entrepreneurship, and the fourth upper left quadrant refers to students who receive influence of external factors with negative influence of social entrepreneurship.

\section{Conclusions}

At the beginning of this work, it was proposed to advance in the understanding of the determining factors that profile the social entrepreneur, which was carried out from a Principal Components Analysis (ACP), which showed that the seven variables chosen (creativity / innovation; self-confidence / internal control; adaptability / tolerance to failure; perseverance / commitment; knowledge of the environment; social empathy; entrepreneurial university) were highly correlated with the internal and external dimensions that influence young university students and their social entrepreneurship profile. Also, according to the ACP performed, the seven factors that were studied in 515 university students can be grouped into internal and external categories (Figure 3).

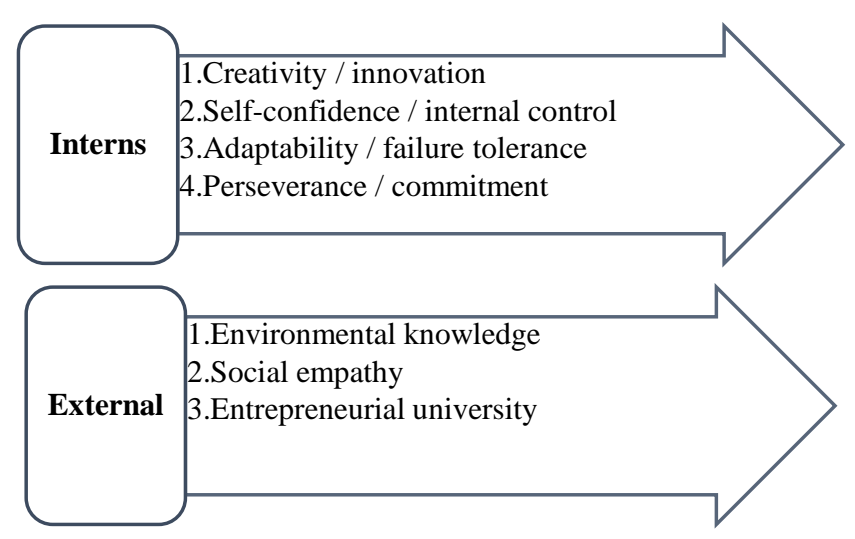

Figure 3 Social entrepreneurship factors Source: own source

The above is consistent with other studies in which it has been rescued that factors such as innovation, persistence, will, commitment, change, value, social utility, inclusion, altruism, among others, are those that stand out in the profile of the social entrepreneur (Caldera , Ortega and Sánchez, 2016).

In addition to the above and relating it to our research subject, Camisón and Gómez (2018) affirm that the teaching of entrepreneurship in higher education must integrate knowledge about the start-up and management of a company, the elaboration of real business plans and the skills that allow them to evaluate business opportunities; However, as we have discussed in this document, there must also be internal factors that favor entrepreneurship, factors that have to do with individual attitudes, behaviors and motivations. 
As future lines of research, the aim is to improve the instrument considering the factors not studied to understand more fully the profile of the young social entrepreneur university, factors identified thanks to the documentary review carried out in the first stage of this research.

\section{References}

Becerra, M. E., Cortés, E. M., Malacara, A. R., y Alegria, N. L. (2014). Factores detonantes del empredimiento social, una alternativa de desarrollo económico y social para la Costa Norte de Jalisco. Guadalajara: Anuario de Investigación UNIVA.

Caldera, D.D.C., Ortega, M.A., y Sánchez, M.E. (2016). The social entrepreneur. A brief characterization. ECORFAN Journal-Republic of El Salvador, 2(3), 19-28.

Caldera, D.D.C. (2019). Factores determinantes de emprendedurismo social en jóvenes universitarios. Proyecto de Investigación 2019, Dirección de Apoyo a la Investigación y el Posgrado de la Universidad de Guanajuato. México.

Camisón, C., y Gómez, J. M. (Eds.). (2019). Diagnóstico del Espíritu Emprendedor y la actitud ante el emprendimiento de los jóvenes preuniversitarios de la Comunidad Valenciana. Universitat de València.

Capella, C., Gil, J., Martí, M., y Ruiz, P. (2016). Construcción de un cuestionario para medir el emprendimiento social en educación física. Pedagogía Social, 28, 169-188.

Corti, E., y Riviezzo, A. (2008). Hacia la universidad emprendedora: un análisis del compromiso de las universidades italianas en el desarrollo económico y social. Economía industrial, $368,113-124$.

Leiva, J. C. (2013). ¿Quién crea MIPYMES En Costa Rica? TEC Empresarial, 7(2), 9-17.

Mancilla, C., y Amorós, J. E. (2012). La influencia de factores socios-culturales en el emprendimiento, evidencia en Chile 2007-2010. Multidiciplinary Business Review, 5(1), 14-25.
Martínez, S., y Rodríguez, L. (2013). Emprendedurismo social en México: hacia un modelo de innovación para la inserción social y laboral en el ámbito rural. Estudios Agrarios. Disponible en: https://www.pa.gob.mx/publica/rev_5354/analisis/emprendedurismo.pdf

Marulanda, F. A., y Morales, S. T. (2016). Entorno y motivaciones para emprender. Escuela de administración de negocios, 81, 1228.

Messina, M., y Hochsztain, E. (2015). Factores de Éxito de un Emprendimiento: Un estudio exploratorio con base a las Técnicas de Data Mining. TEC Empresarial, 9(1), 31-40.

Messina, M., y Hochsztain, E. (2015). Factores de Éxito de un Emprendimiento: Un estudio exploratorio con base a las Técnicas de Data Mining. TEC Empresarial, 9(1), 31-40.

Mora, P., Aguirre, J. C., Álava, N.G. y Cordero, J.F. (2019). Jóvenes universitarios y su apuesta al emprendimiento social. Revista Economía y Política, 5 - 23.

Palmero, F. (2005). Motivación: conducta y proceso. Revista Electrónica de Motivación y Emoción, 8(20-21), 1-29.

Pat, J. E., y Basto, A.D.P. (2019). Intención de emprendimiento en estudiantes del ITChetumal, conforme a sus competencias adquiridas. AvaCient, 6(1), 75-94.

Ramírez, W., Antúnez, G. y Rodríguez, Y. (2016). La utilización del Análisis de los Componentes Principales en la Medicina Veterinaria. REDVET. Revista Electrónica de Veterinaria, 17 (3), 1-8.

Rodríguez, C. A., y Prieto, F. A. (2009). La sensibilidad al emprendimiento en los estudiantes universitarios. Estudio comparativo Colombia-Francia. Innovar, Especial en Educación, 19, 73-90.

Sánchez, J. C. (2010). Evaluación de la Personalidad Emprendedora: Validez Factorial del Cuestionario de Orientación Emprendedora (COE). Revista Latinoamericana de Psicología, 42(1), 42-52. 
Sepúlveda, C. I., y Gutiérrez, R. (2016). Sostenibilidad de los emprendimientos: Un análisis de los factores determinantes. Revista Venezolana de Gerencia, 21(73), 33-49.

Solanas, A., Manolov, R. Leiva, D., y Richard's, M. (2011). Retaining principal components for discrete variables. Anuario de Psicología, 41 (13), 33-50.

Torné, I. S. y Suárez, M. P. (2019). El impacto de la educación en la intención emprendedora de los estudiantes del grado de economía. Revista de Estudios Empresariales.Segunda época, (1), 22-40.

Valencia, J. A., Montoya, I., y Montoya, A. (2015). Factores explicativos de las intenciones emprendedoras en estudiantes universitarios. Espacios, 36(5). Obtenido de http://www.revistaespacios.com/a15v36n05/15 360507.html\#intro 